\title{
Assessing the Influence of Financial Sector Development on Kenya's Economic Growth
}

\author{
Beatrice Kinanu Anyuki ${ }^{1} \quad$ Sandra Beldine Otieno $^{2 *} \quad$ Dr. Grace Akinyi Musa ${ }^{3}$ \\ 1. PhD Student, Department of Accounting and Finance, University of Nairobi, Nairobi, Kenya \\ 2.Economist/ Data analyst, Nairobi, Kenya \\ 3. Lecturer, Department of Accounting and Finance, Technical University of Kenya
}

\begin{abstract}
The relationship between financial sector development and economic growth is a crucial issue for both developing and developed nations. To keep up with the changing world economy, there is need for developing countries like Kenya to develop their financial sectors. Kenya's financial sector development has had a major role in its economic growth and this study provides a selected review of the literature and the relationship between Kenya's financial sector and its economic growth. Numerous studies have been done on the effect of the financial sector on economic growth and the general conclusion is that the financial sector plays a central role in economic development and growth of the country. However, there is a limitation of empirical and theoretical work supporting the concept in developing countries. Most of the studies done focus on the direction of causality between finance development and economic growth and their relationship. For this reason, the study set out to analyze the influence of financial sector development on Kenya's economic growth. The Neo-classical theory of growth was used to inform the study variables; banking sector, export market and economic growth. The study adopted an ex-post facto research design with Ordinary Least Square (OLS) method. The data used was secondary in nature obtained from the Kenya National Bureau of Statistics from the period 2010-2019. The findings revealed that there was a positive influence of financial sector development on economic growth. This implies that financial sector development promotes economic growth in Kenya. In policy terms, the findings, imply that Kenya can accelerate economic growth by improving the financial sector since financial development can be an engine of growth in this country. The study recommended that other major components of the financial sector development apart from the two studied; banking sector and export market, in this paper should be studied and put up in place well -structured policies that will support them and further develop the financial sector with the aspirations under the Kenya Vision 2030.
\end{abstract}

Keywords: Financial sector development, Economic growth

DOI: $10.7176 /$ RJFA/12-2-01

Publication date: January $31^{\text {st }} 2021$

\section{Introduction}

Economic growth is vital to every country across the world. This is majorly because economic growth means reduced poverty levels, reduced unemployment, improved government budget and improved living standards which is depicted by good education, better healthcare without an increase in tax rates (Straubhaar, 2003). Financial development on the other hand is concerned with reducing costs incurred within the financial system. Financial development includes the expansion of financial services and the growth of financial institutions as well as an increase in per capital amount of financial services and institutions or an increase in the ratio of financial assets to income (Ahmed \& Ansari, 1998). It is the process of reducing costs of information acquisition, enforcement of contracts and execution of transactions which results in the emergence of markets and intermediaries and financial contracts. Financial development through financial intermediaries ensures that the exchange is affordable by eliminating market imperfections and frictions. To ensure that a great financial system is in place, there must be financial sector local reforms which is the engine to ensure improvements for the extension of prosperity.

Financial sectors are policies, factors and institutions which ensure that financial markets and institutions are effective and that participants are able to easily access funds/capital and other financial services (Drexler, et al., 2012). Financial markets play a vital part in the growth of the real economy and specifically the role of the banking sector as an accelerator of economic growth due to its role as a financier of productive investments. A welldeveloped financial sector may increase investments, which again can promote economic growth (Beck \& Levine, 2000). Associated with every investment are the costs of completing a transaction. A developed financial sector may decrease transactions costs, as well as credit constraints, conditions which may retard the economic growth in a country. A financial sector that is not functioning well can by its malfunctioning result in little economic activity and growth. The lack of well-functioning financial markets may constrain credit demanded to investments that spur economic growth. This potential 'loan rationing' can have a negative effect as allocated credit is substantial for technological progress and capital accumulation. The development of the financial sector, especially in developing countries, is seen as a part of the growth strategy of the private sector, which aims to stimulate economic activity and reduce poverty by generating local savings, which in turn lead to productive investments 
and better resource allocation. This process is supposed to increase an investor's borrowing options, thus allowing him or her to choose an optimal debt structure for a given period (Mihalca, 2007).

Kenya's financial sector can be described as young and growing. The sector is also a crucial participant in the country's Vision 2030. The Kenya Vision 2030 is a development blueprint launched in 2007. For financial services, it aims to create a vibrant and globally competitive financial sector in Kenya that will create jobs and promote high level of savings to finance Kenya's overall investment needs (Republic of Kenya, 2007). Therefore, it is key in promoting economic growth. Furthermore, the financial sector is divided into two: the formal and informal. The formal sub-sector comprises of the banking, insurance, capital markets, and pension funds, Savings and Credit Cooperative Societies (SACCOs), Development Finance Institutions, Central Bank of Kenya (2011). This sector also includes the financial infrastructure that facilitates trading, payments and settlement systems. On the other hand, the informal financial sub-sector is a sector that is unregulated but offers financial services. The institutions and group that are included here are the Rotating Savings and Credit Associations (ROSCAs) and Accumulating Savings and Credit Association (ASCAs), merry go rounds popularly known as chamas in Kenya, shopkeepers and moneylenders, Central Bank of Kenya (2011). The Kenyan financial sector is dominated by commercial banks.

The relationship between financial development and economic growth has been extensively analyzed. Most empirical studies conclude that financial development, together with a more efficient banking system, accelerates the latter. Levine (2005) suggests that financial institutions and markets can foster economic growth through several channels; easing the exchange of goods and services through the provision of payment services, mobilizing and pooling savings from a large number of investors, acquiring and processing information about enterprises and possible investment projects, thus allocating savings to their most productive use, monitoring investment and carrying out corporate governance, and diversifying, increasing liquidity and reducing intertemporal risk. Each of these functions can influence saving and investment decisions and hence economic growth. Since many market frictions exist and laws, regulations, and policies differ markedly across economies and over time, improvements along any single dimension may have different implications for resource allocation and welfare depending on other frictions in the economy. For this reason, the current study seeks to assess the relationship between finance sector development and economic growth by studying two major components of the finance sector; banking development and export market.

\subsection{Statement of the Problem}

Most African countries, Kenya included went through an era of financial reforms in the mid-1980s. This was motivated by the on-going structural adjustment programs articulated by the World Bank and IMF, as well as efforts to step up the slow growth rates experienced in the 1970s. In most countries, the thrust of the reform agenda focused on liberalizing interest rates, deregulation of the financial sector, strengthening the banking system, introduction of new financial instruments, and development of securities markets, especially the stock market. Given the increasing desire for growth improvement in most African countries, development of the financial sector has attracted considerable attention from policy makers across the continent. Numerous studies have been done in relation to financial development and economic growth. A study by (Caporale, Rault, Sova, \& Sova, 2009), whose main aim was to establish the relationship between financial development and economic growth in ten Countries that were new European Union members. The study showed there was a positive relationship between financial depth in the credit sector and economic growth.

However, there have been controversial debates regarding the relationship of financial sector development and economic growth from empirical studies in the world. The thrust of these debates is on whether financial sector development causes economic growth which is supply leading or economic growth causes financial sector development which is demand leading. (Wolde-Rufael, 2009). Recent studies across the globe show the magnitude of the effects of the financial crisis is still felt by both developed and emerging economies. Europe continues to be overwhelmed by debt hangover, high rate of unemployment, high political divisiveness and lack of universal competitiveness. The U.S.A also faces political stalemate during uncertain fiscal time and public debt increase. Emerging market powers like China and Brazil are experiencing slowdown in their economies which may have significant effect for world trade (Drexler, et al., 2012).

Levine (1997), in describing the conceptual links between the functioning of the financial system and economic growth, highlighted areas needing additional research and he stated that there was no sufficient and rigorous understanding of the emergence, development, and economic implications of different financial structures. In addition, there are no adequate theories of why different financial structures emerge or why financial structures change. Furthermore, there is need to develop an analytical basis for making comparisons of financial structures. Kenya's financial sector can be described as young and growing. The sector is also a crucial participant in the country's Vision 2030. The Kenya Vision 2030 is a development blueprint launched in 2007. For financial services, it aims to create a vibrant and globally competitive financial sector in Kenya that will create jobs and promote high level of savings to finance Kenya's overall investment needs (Republic of Kenya, 2007). Therefore, it is key in 
promoting economic growth. There is need for more research to be done as far as Kenya's financial sector is concerned. For this reason, the study sought to analyze the influence of financial sector development on Kenya's economic growth.

\subsection{Objectives of the Study}

The main objective of the study was to assess the relationship between Financial Sector Development and Kenya's economic growth.

The specific objectives were;

i. To analyze the influence of banking development on Kenya's economic growth.

ii. To analyze the influence of export market on Kenya's economic growth.

\subsection{Null Hypothesis}

The following hypotheses were formulated based on the study's objectives;

H01: There is no influence of banking development on Kenya's economic growth.

Ho2: There is no influence of export market on Kenya's economic growth.

\section{Literature Review}

The study reviewed both theoretical and empirical literature. Theoretical literature was based on Neo-classical theory of growth. Empirical literature compared past against current study and thereby highlighted gaps. The study used the following variables; banking development, exports markets and economic growth.

\subsection{Neo-classical theory of growth}

The Neo-classical theory of growth was coined by two economists; Robert Solow and Trevor Swan in 1956. It outlines the three factors necessary for a growing economy; labor, capital and technology (Meade, 2013). The theory states that short-term equilibrium results from varying amounts of labor and capital in production. It also argues that technological change has a major influence on an economy, and economic growth cannot continue without technological advances. This growth theory posits that the accumulation of capital within an economy, and how people use that capital, is important for economic growth. Further, the relationship between the capital and labor of an economy determines its output. Finally, technology is thought to augment labor productivity and increase the output capabilities of labor (Meade, 2013).

The theory is relevant to the study due to a number of factors. The financial sector in Kenya has seen a tremendous improvement in as far as capital, labor and technology are concerned. Capital is accumulated in various ways, majority of the country's businesses being Small and Medium Enterprises (SMEs), loans are the major source of funding (Shikumo \& Mwangi, 2016). As more businesses are established, a working force is needed; employment opportunities are created. Both skilled and unskilled labor are required for the normal running of businesses. Technological advancement has also improved the finance sector; the banking sector for example through the use of Automated Teller Machines (ATMs), mobile and internet banking (Musa, Moro, \& Otieno, 2020).

The theory has been critiqued by a number of researchers who opted for the Endogenous theory of growth which was developed in the 1980s by Paul Romer. The theory questioned how the gaps between developed and underdeveloped countries could persist if investment in physical capital like infrastructure is subject to diminishing returns. The theory purports that economic growth is influenced by internal processes such as human capital, innovation and investment capital rather than external and uncontrollable forces (Mishra, 2016). A study by (Abbas, 2001) emphasized the role of investment in human capital as an important factor contribution to economic growth. An additional role for human capital as an engine for attracting other factors such as physical investment, which also contribute measurably to per-capita income growth. Recent experience with attempts to accumulate physical capital at a rapid rate in under-developed countries bears out the necessity of due attention to human capital because it has become evident that the effective use of physical capital itself dependent on human capital. If there is underinvestment in human capital, the rate at which additional physical capital can be productively utilized is limited since technical, professional, and administrative people are needed for the effective use of physical capital.

Despite the critics, the theory informed the study variables given; banking sector, export market and economic growth. The theory has been used in a number of studies, (Muli, 2014) concluded that the Neo-classical theory was relevant due to the suggestion that capital and labor determine Kenya's financial system. Additionally, technological advancement together with labor and capital are the main determinants of a country's economic growth.

\subsection{Empirical Review}

A number of studies have been done investigating the relationship between economic growth and financial 
development. These range from cross country to country specific, using cross sectional data and time series data. Various models have also been used; regression models, Error Correction Models (ECM) among others.

A study by (Caporale, Rault, Sova, \& Sova, 2009), whose main aim was to establish the relationship between financial development and economic growth in ten Countries that were new European Union members. The paper reviewed the main features of the banking and financial sector in ten new EU members, and then examined the relationship between financial development and economic growth in these countries by estimating a dynamic panel model over the period 1994-2007. The evidence suggested that the stock and credit markets are still underdeveloped in these economies, and that their contribution to economic growth was limited owing to a lack of financial depth. By contrast, a more efficient banking sector is found to have accelerated growth. Furthermore, Granger causality test indicate that causality runs from financial development to economic growth, but not in the opposite direction. The study, therefore, showed there was a positive relationship between financial depth in the credit sector and economic growth. The study was similar to the current study since it implied influence of financial sector development on economic growth.

A Nigerian study by (Umar, Dayyabu, Gambo, \& Danlami, 2015) empirically investigated the relationship between financial intermediaries and economic growth in Nigeria. Annual time series data covering 1970 to 2013 was used to analyze the long run and short run relationship between the development of financial intermediaries and economic growth along with the direction of causality between the indicators. Using bound testing technique for co-integration, a stable long-run relationship was found between the indicators of financial intermediaries and the economic growth. Error correction coefficient was statistically significant. It was concluded that insurance premium and value of stock transaction had a positive impact on economic growth in both the short-run and longrun. However, bank credit had a negative influence on economic growth. The causality test reveals a bi-directional relationship between bank credit and economic growth while a unidirectional causality moves from economic growth to insurance premium and value of stock transactions.

A Kenyan study by (Muli , 2008), sought to empirically explore the causal link between the level of financial development and economic growth in Kenya for the period 1967 to 2006 . The study applied both the Grangercausality analysis and Error Correction Model. The results of the co-integration analysis provided evidence of a stable long-run relationship between economic growth and financial development in Kenya. However, the study did not explain the nature of the relationship. The financial services sector is the largest in the world in terms of earnings. Despite this potential to date the impact of large commercial banks on expanding economic opportunity has remained limited to the developing countries, where a vicious cycle of insufficient information, inappropriate products, inadequate infrastructure and inflexible regulatory environment has kept costs and their prices high limiting companies' markets to clients within the top tiers of economic pyramid.

A study by (Muli , 2014) asserted the role of banking sector in financial development. According to the study, the banking industry is responsible for pooling and trading risks in the market. This is through facilitating lenders to have liquidity that was enough to finance investment projects that are long term in nature. Banks improve the economy through intermediation which enables savers save and access their funds immediately while assuring borrowers of long term access to finances. The industry diversifies the liquidity risk that lenders face thus enabling them to avoid loses as a result of risk; this enhances economic growth. This is at par with the current study that seeks to assess the influence of banking sector in economic growth.

A study by (Bakang, 2015), sought to investigate the effects of financial deepening on economic growth in the Kenyan banking sector. The study achieved this objective by using quarterly time series data from 2000 to 2013. The study found that banking sector in Kenya has an important role in the process of economic growth. The empirical results revealed that liquid liabilities, credit to the private sector, commercial central bank assets and commercial bank deposits have positive and statistically significant effects on Gross Domestic Product. The study recommends reinforcing existing policies that will encourage the public to save more money with commercial banks. Increasing the interest rate paid to depositors on their deposits for example, will incite people to save more. In addition, the study recommends the intensification of financial inclusion policies through increased access and usage of formal banking services while reducing banks transaction costs. Therefore, the study had conflicting results on what exactly influences the other.

A South African study by (Rangasamy, 2009) on exports and economic growth, The study purported that economic policy has always accorded an important role to export production in the overall growth process in South Africa. The paper attempted to ascertain whether the emphasis on export production is justified. Using modern econometric techniques within a multivariate framework, the results showed that there was a uni-directional Granger-causality running from exports to economic growth in South Africa. In addition, the gross domestic product (GDP) accounting identity underestimates the contribution of exports to economic growth. Thus, deliberate policy measures that stimulate export production will greatly enhance the growth prospects for the South African economy. Similarly, the current study seeks to assess the influence of the export market in Kenya's economic growth.

It is clear from the empirical studies assessed that majority of them focus on the relationship between financial 
development and economic growth. Little literature exists with regards to the influence of financial sector development on economic growth. The current study seeks to fill this contextual gap.

\subsection{Conceptual Framework}

The conceptual framework showed the relationships between the independent variables; Banking sector and export market and dependent variable; Economic Growth.

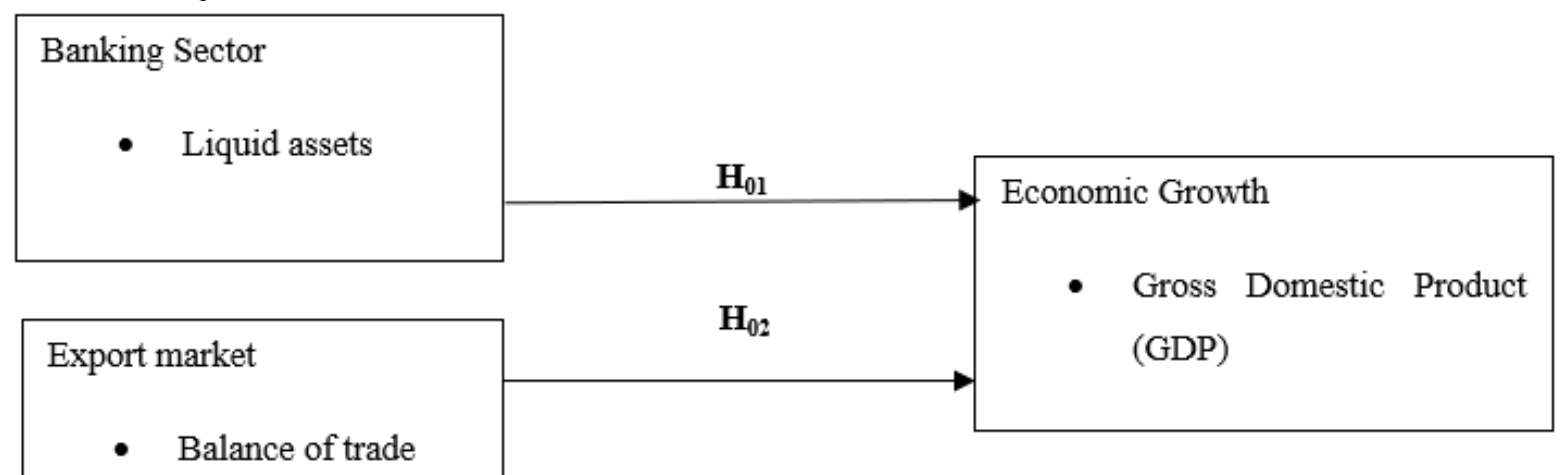

\section{Independent Variables}

\section{Dependent variable}

Figure 1: Conceptual Framework

Source: Authors (2020)

$\mathbf{H}_{01}$ : Depicts a direct relationship between the banking sector and economic growth.

Ho2: Depicts a direct relationship between the export market and economic growth.

From the conceptual framework above, it is clear that the banking sector provides assets which may be in form of capital to businesses in the country this in turn has an effect of improving the country's economic growth. On the other hand, when there is a surplus in the balance of trade that is when the exports are more than the imports in the export market; it contributes to the economic growth.

\section{Methodology}

The study adopted an ex-post-facto research design. It sought to assess the influence of financial sector development on Kenya's economic growth. The design was appropriate for the study since it can be used to test hypotheses about cause and effect or co-relational relationships. In an ex-post facto design, attempts are made to determine the influence of a variable on another variable and test a state using statistical hypothesis testing techniques (Tunji, 2012). The study relied heavily on secondary data. The time series data was obtained from Kenya National Bureau of Statistics (KNBS) the period; 2010-2019. Ordinary Least Square (OLS) method was used to obtain the regression coefficients thus testing the hypotheses formulated by the study.

\section{Data Analysis}

Data obtained from Kenya National Bureau of Statistics (KNBS) was analysed and the following was established: Table 1: Regression model of Banking Sector and Economic Growth

\begin{tabular}{|c|c|c|c|c|c|}
\hline \multicolumn{6}{|c|}{ Model Summary } \\
\hline $\mathrm{R}$ & $\mathrm{R}^{2}$ & Adjusted $\mathrm{R}^{2}$ & Std. Error & F Change & Sig. \\
\hline .629 & .413 & .408 & 6.538 & 89.45 & .001 \\
\hline \multicolumn{6}{|c|}{ Regression Coefficients } \\
\hline & & Beta & Std. Error & t-statistics & Sig. \\
\hline$(\mathrm{Col}$ & & 7.984 & .609 & 15.451 & .000 \\
\hline Bank & ctor & 3.049 & .324 & 9.872 & .001 \\
\hline
\end{tabular}

Table 1 shows a positive relationship between Banking Sector and Economic Growth $(R=0.629)$. Also, the value 0.413 indicates that the banking sector only explains $41.3 \%$ of the total variations in economic growth. Consequently, banking sector explains only $40.8 \%$ of changes in economic growth as represented by the adjusted $\mathrm{R}^{2}$. It can therefore be concluded that there are other factors not included in this study that contribute $59.2 \%$ of the changes in economic growth. The model is however significant since the p-value 0.001 is less than 0.05 .

From the regression coefficients, the constant regression coefficient and that of the independent variable were $7.984(S E=0.609)$ and $3.049(S E=0.324)$ respectively. These regression coefficients were both significant at $5 \%$ level since the $\mathrm{p}$-values were less than 0.05 .

The coefficient value for the independent variable implied that for every improvement in the pre-specified 
aspects of banking sector by one unit, would result to improvement in economic growth by 3.049 units. Thus, based on the significance of the regression coefficient, we express the equation for the simple regression model as follows:

$$
Y=3.049 X+7.984
$$

The study rejected the null hypothesis $\left(\mathrm{H}_{01}\right)$ at 5\% level of significance about the non-significance of the influence of banking sector in economic growth in Kenya.

Table 2: Regression model of Export Market and Economic Growth

\begin{tabular}{lccccc}
\hline \multicolumn{5}{c}{ Model Summary } \\
\hline $\mathrm{R}$ & $\mathrm{R}^{2}$ & Adjusted $\mathrm{R}^{2}$ & Std. Error & F Change & Sig. \\
\hline .529 & .373 & .358 & 4.338 & 59.45 & .002 \\
\hline \multicolumn{5}{c}{ Regression Coefficients } \\
\hline Beta & Std. Error & t-statistics & Sig. \\
\hline (Constant) & 3.954 & .457 & 9.641 & .001 \\
Export Market & 3.239 & .209 & 6.562 & .003 \\
\hline
\end{tabular}

Table 2 shows a positive relationship between Export Market and Economic Growth $(R=0.529)$. Also, the value 0.373 indicates that Export Market only explains $37.3 \%$ of the total variations in economic growth. Consequently, Finance Specialization explains only $35.8 \%$ of changes in economic growth as represented by the adjusted $\mathrm{R}^{2}$. It can therefore be concluded that there are other factors not included in this study that contribute $64.2 \%$ of the changes in economic growth. The model is however significant since the p-value 0.002 is less than 0.05 .

From the regression coefficients, the constant regression coefficient and that of the independent variable were $3.954(S E=0.457)$ and 3.239 $(S E=0.209)$ respectively. These regression coefficients were both significant at $5 \%$ level since the p-values were less than 0.05 .

The coefficient value for the independent variable implied that for every improvement in the pre-specified aspects of export market by one unit, would result to improvement in economic growth by 3.239 units. Thus, based on the significance of the regression coefficient, we express the equation for the simple regression model as follows:

$$
Y=3.239+3.954
$$

The study rejected the null hypothesis $\left(\mathbf{H}_{02}\right)$ at 5\% level of significance about the non-significance of the influence of export market development on Kenya's economic growth.

\subsection{Findings}

The first objective of the study was to analyse the influence of banking sector development on Kenya's economic growth. The study established that there was a significant influence of banking sector on Kenya's economic growth. These findings were at par with a study by (Bakang, 2015) which established that banking sector in Kenya has an important role in the process of economic growth. The empirical results revealed that liquid liabilities, credit to the private sector, commercial central bank assets and commercial bank deposits have positive and statistically significant effects on Gross Domestic Product; a measurement of economic growth.

The second objective of the study was to analyse the influence of export market development on Kenya's economic growth. The study had hypothesized that there was no influence of export market on economic growth in Kenya. The study established that there was a significant influence of export market on Kenya's economic growth. These findings were consistent with a South African study by (Rangasamy, 2009) on exports and economic growth, The study purported that economic policy has always accorded an important role to export production in the overall growth process in South Africa. The paper attempted to ascertain whether the emphasis on export production is justified. In addition, the gross domestic product (GDP) accounting identity underestimates the contribution of exports to economic growth. Thus, deliberate policy measures that stimulate export production will greatly enhance the growth prospects for the South African economy.

\subsection{Limitations, Justifications and Suggestions for Future Researchers}

Conceptual Limitation: The current study concentrated on banking sector and export market and economic growth. Other variables could have been applied in the same study such as risk management and stock market. However, this did not compromise the quality of the study as the variables helped in achieving the set objectives and hypothesis developed. Future researchers should consider using other variables not considered by the current study. Theoretical Limitation: The current study applied the Neo-classical theory of growth. It could have applied other economic growth theories. However, this did not compromise quality of the research. The theory used informed the study variables. Future studies should consider using other economic growth theories for example the Keynesian Theory of Growth left out by the current study.

Methodological Limitation: The study adopted ex-post facto research design. However, this did not 
compromise the quality of research. Future studies should consider other designs such as time series and longitudinal research design. Furthermore, the study used the Ordinary Least Square method other methods for data analysis should be considered.

\section{Conclusion}

Financial Sector Development: There is need for development of the Finance Sector. This is because the finance sector directly influences Kenya's Economic Growth. This should be done in terms of technological advances; better technology means better performances. Secondly the issue of capital for start-up businesses for example SMEs require funds for their daily running. Thus bank regulations should be able to accommodate the needs of such businesses. Lastly, the need for labour by creating job opportunities for the highly unemployed youth population in the country

Government of Kenya: Being Kenya's governing body, the government should make policies that are inclined towards improving the country's economic growth. Furthermore, the country's Vision 2030 advocates for the improvement of the financial sector. Thus, the Kenyan government should work towards achieving this goal.

Unemployment in Kenya: The issue of open involuntary unemployment in the country is a worrying trend. This is because there are too many people chasing few jobs. If the financial sector is improved more avenues would be created for such people to be employed thus raising their standards of living. This in turn has an effect of improving the economic growth.

\section{References}

Abbas, Q. (2001). Endogenous Growth and Human Capital:A Comparative Study of Pakistan and Sri Lanka. The Pakistan Development Review, 987-1007.

Ahmed, S., \& Ansari, M. I. (1998). Financial sector development and economic growth: The South-Asian experience. Journal of Asian Economics, 503-517.

Bakang, M. L. (2015). Effects of Financial Deepening on Economic Growth in Kenya. International Journal of Business and Commerce, 1-50.

Beck, T., \& Levine, R. (2000). Financial Structure and Economic Development: Firm, Industry, and Country Evidence. Financial Structure and Economic Growth.

Caporale, G. M., Rault, C., Sova, R., \& Sova, A. (2009). Financial Development and Economic Growth:Evidence from Ten New EU Members . Deutsches Institut für Wirtschaftsforschung.

Drexler, M., Hanouz, M. D., Duffie, D., Geiger, T., Glass, T., Reuttner, I., \& van Horen, N. (2012). The Financial Development Report. New York: World Economic Forum.

Meade, J. E. (2013). A Neo-Classical Theory of Economic Growth. Routledge.

Mihalca, G. (2007). The relation between financial development and economic growth in Romania. 2nd Central European Conference in Regional Science - CERS (pp. 719-725). Technical University of Košice, Faculty of Economics.

Mishra, S. (2016). The New Theory of Economic Growth: Endogenous Growth Model. International Journal of Business and Management Invention, 50-53.

Muli, A. (2008). Financial development and economic growth in Kenya. University of Nairobi.

Muli, P. W. (2014). The effect Of Financial Sector Development on the Economic Growth of Kenya. University of Nairobi.

Musa, G. A., Moro, P. A., \& Otieno, S. B. (2020). An Assessment of Customers' Adaptability to Technological Innovations in Kenya's Banking Industry: Effects of Customers Perceptions. Research Journal of Finance and Accounting, 14-21.

Rangasamy, L. (2009). Exports and economic growth: The case of South Africa. Journal of International Development, 603-617.

Shikumo, D. H., \& Mwangi, M. (2016). Determinants of Lending to Small and Medium Enterprises by Commercial Banks in Kenya. IOSR Journal of Economics and Finance, 7(4), 57-63.

Straubhaar, T. (2003). Why is growth so important? Intereconomics: Review of European Economic Policy, 290291.

Tunji, S. T. (2012). Accounting Information as an aid to management decision making. International Journal of Management and Social Sciences Research.

Umar, M. B., Dayyabu, S., Gambo, A. U., \& Danlami, M. R. (2015). An Empirical Study on the Relationship between Financial Intermediaries and Economic Growth in Nigeria: A Cointegration and Causality Analysis. IOSR- Journal of Economics and Finance, 15-31.

Wolde-Rufael, Y. (2009). Re-examining the financial development and economic growth nexus in Kenya. Economic Modelling, 1140-1146. 